\title{
The Economics of Tropical Deforestation and Land Use: An Introduction to the Special Issue
}

Edward B. Barbier

ABSTRACT. This paper both introduces the special issue on the economics of tropical deforestation and land use and conducts a synthesis crosscountry analysis of tropical agricultural land expansion. Agricultural development is the main factor determining land expansion, but institutional factors have an important influence. Income effects vary from region to region, and do not always display an EKC relationship. The case studies comprising this special issue provide further case study insights into tropical deforestation and land use, through spatial analysis of locational factors, CGE modeling of policy scenarios, assessing external market impacts on land clearing, and modelling state interventions and taxation. (JEL Q2, Q23)

\section{INTRODUCTION}

Although global forest loss has occurred for centuries, rapid rates of tropical deforestation have only become an international concern in the last twenty-five years or so. As is the usual case with such phenomena, it was not economists but natural scientists who initially called the world's attention to the potential consequences of tropical forest destruction, whether it be biodiversity loss, climate change, or the loss of traditional livelihoods of indigenous peoples. ${ }^{1}$ Economists began studying such problems in the mid1980s, and since then, there has been steady progress in the economic analysis of tropical forest loss.

The "first wave" of studies focused on the economic causes of tropical deforestation and tended to be dominated by statistical analyses across tropical countries, or for selective countries and regions. More recently, a "second wave" has focused on modeling and analyzing the economic behavior of

Land Economics • May 2001 • 77 (2): 155-171

ISSN 0023-7639 (c) 2001 by the Board of

Regents of the University of Wisconsin System agricultural households, timber concessionaires, and other agents within tropical countries who affect deforestation through their land use decisions. In some cases, the modeling has centered on a single representative agent of a sector (e.g., an agricultural household or a timber concessionaire). In others, the use of general equilibrium models has facilitated the integration of several key economic sectors (e.g., commercial agriculture, subsistence agriculture, and forestry) to analyze both their individual and collective impacts on deforestation.

The following special issue consists mainly of "second wave" studies of tropical forest land use and deforestation. The articles were chosen with several criteria in mind. First, they hopefully indicate the breadth of new economic modeling approaches currently being applied in developing countries. Second, these models are applied empirically to a range of economic and institutional policy influences on tropical land use decisions.

As a result, the articles combine innovative conceptual approaches with original em-

The author is John S Bugas Distinguished Professor of Natural Resource and Environmental Economics, Department of Economics and Finance, University of Wyoming. He is grateful to Joanne Burgess for assisting him on data preparation for the analyses contained in this paper, for providing useful comments, and for co-editing this special issue with me. Jo Burgess and I would like to thank Daniel Bromley for his enthusiastic support and advice in preparing this issue, Clare Meadley for her assistance with coordinating the manuscript submission and review process, and Carol Olsen for managing the final stages of preparing this issue. We would also like to acknowledge our debt to the many anonymous reviewers who agreed to referee the submitted papers and who provided excellent and timely reviews that proved extremely helpful to both the authors and us. Finally, we would like to thank the authors whose papers appear in this special issue for joining us in this collective effort, and for producing such excellent studies on our tight deadlines.

${ }^{1}$ One of the first to popularize the scientific concerns over tropical deforestation was Myers (1979). 
pirical analyses to the problem of tropical deforestation and land use. Third, the articles were also selected to include case studies from the three main tropical regions of the world: Africa, Asia, and Latin America. The countries covered in this special issue are Brazil (Cattaneo), India (Köhlin and Parks), Malaysia (Amacher, Brazee, and Witvliet), Panama (Nelson, Harris, and Stone), the Philippines (Coxhead, Rola, and Kim and Shively), Thailand (Cropper, Puri, and Griffiths) and Uganda (Bashaasha, Kraybill, and Southgate). Last, but certainly not least, it is hoped that the papers in this issue would prove to be inspirational to those interested in pursuing further research in this topic, whether this involves conducting follow-up work to the country studies reported here or pursuing entirely new case studies in other tropical forest countries and regions.

The purpose of this introductory article is twofold. First, it has the standard objective of introducing the collection of papers that comprise the special issue. However, an additional aim is to provide a bridge between the two current "waves" of research into the economic analysis of tropical forest land use. Improving the statistical analysis of the factors determining tropical forest loss is still an important area of research. More importantly, insights gained from cross-country analysis of tropical deforestation may still inform case study analyses of the economic behavior determining land use decisions within specific tropical forest countries and regions. Similarly, new economic modeling approaches and case studies can improve our understanding of the underlying causes and the key processes determining deforestation.

The outline of this introduction is as follows. The next section provides a brief summary of global tropical forest land use trends. This is followed by an overview of crosscountry analyses of tropical deforestation, highlighting the main factors and causes identified by such studies. Four key economic approaches to cross-country analysis are then discussed, and from this a synthesis analysis is proposed and applied to a new cross-country data set. The implications and findings of the analysis are then used as a basis for introducing the articles that comprise this special issue.

\section{OVERVIEW OF DEFORESTATION AND LAND USE TRENDS}

The 1990 Global Forest Resource Assessment (FAO 1993) indicated that the annual deforestation rate across tropical countries over 1981-1990 was approximately $0.8 \%$, or 15.4 million hectares (ha) per annum (see Table 1). Although the highest rate of deforestation occurs in Asia (1.2\%), the area of tropical forests cleared on average each year in Latin America, 7.4 million ha, is almost as much as the forest area cleared in Asia and Africa put together. The largest amount of deforestation is currently occurring in tropical South America (6.4 million ha), followed by Insular South East Asia (1.9 million ha), but the highest rates of deforestation are being experienced in Continental South East Asia (1.6\% annually) and Central America and Mexico (1.5\% annually). ${ }^{2}$

Table 2 shows trends in land area and use for different regions of the world since 1980. Over the last fifteen years in most tropical areas dominated by developing economies, the decline in forest and woodlands is mainly the result of land conversion, in particular agricultural expansion. The loss of permanent pasture may be the result of both the serious degradation problems posed by over-grazing, and also the conversion of pasture land to cropland. Table 3 suggests that the land expansion occurring in tropical regions could be related to structural features of the agricultural sectors of developing economies, such as low irrigation and fertilizer use as well as poor crop yields. Increasing agricultural productivity and input use reflect greater agricultural intensification and development, which in turn mean less pressure is put on conversion of forests and other marginal lands for use in agriculture (Barbier 1997).

\footnotetext{
${ }^{2}$ Although in recent years reforestation through plantation establishment has increased in some tropical countries, this trend has not been sufficient to offset the loss in overall forest areas.
} 
TABLE 1

Global Tropical Deforestation Trends, 1980-1990

\begin{tabular}{|c|c|c|c|c|c|c|}
\hline \multirow[b]{2}{*}{ Region } & \multirow{2}{*}{$\begin{array}{l}\text { Number } \\
\text { of } \\
\text { Countries }\end{array}$} & \multirow[b]{2}{*}{$\begin{array}{l}\text { Land Area } \\
\text { (million ha) }\end{array}$} & \multicolumn{2}{|c|}{ Forest Cover } & \multicolumn{2}{|c|}{$\begin{array}{c}\text { Annual } \\
\text { Deforestation } \\
1981-90\end{array}$} \\
\hline & & & $\begin{array}{c}1980 \\
\text { (million ha) }\end{array}$ & $\begin{array}{c}1990 \\
\text { (million ha) }\end{array}$ & $\begin{array}{c}\text { Million } \\
\text { ha }\end{array}$ & $\begin{array}{l}\% \text { per } \\
\text { annum }\end{array}$ \\
\hline Africa & 40 & $2,236.1$ & 568.6 & 527.6 & 4.1 & 0.7 \\
\hline West Sahelian Africa & 6 & 528.0 & 43.7 & 40.8 & 0.3 & 0.7 \\
\hline East Sahelian Africa & 9 & 489.7 & 71.4 & 65.5 & 0.6 & 0.9 \\
\hline West Africa & 8 & 203.8 & 61.5 & 55.6 & 0.6 & 1.0 \\
\hline Central Africa & 6 & 398.3 & 215.5 & 204.1 & 1.1 & 0.5 \\
\hline Trop. Southern Africa & 10 & 558.1 & 159.3 & 145.9 & 1.3 & 0.9 \\
\hline Insulfar Africa & 1 & 58.2 & 17.1 & 15.8 & 0.1 & 0.8 \\
\hline Asia and Pacific & 17 & 892.1 & 349.6 & 310.6 & 3.9 & 1.2 \\
\hline South Asia & 6 & 412.2 & 69.4 & 63.9 & 0.6 & 0.8 \\
\hline Continental S.E. Asia & 5 & 190.2 & 88.4 & 75.2 & 1.3 & 1.6 \\
\hline Insular S.E. Asia & 5 & 244.4 & 154.7 & 135.4 & 1.9 & 1.3 \\
\hline Pacific & 1 & 45.3 & 37.1 & 36.0 & 0.1 & 0.3 \\
\hline \multicolumn{7}{|l|}{ Latin America and } \\
\hline C. America and & & & & & & \\
\hline Mexico & 7 & 239.6 & 79.2 & 68.1 & 1.1 & 1.5 \\
\hline Caribbean & 19 & 69.0 & 48.3 & 47.1 & 0.1 & 0.3 \\
\hline Trop. South America & 7 & $1,341.6$ & 864.6 & 802.9 & 6.2 & 0.7 \\
\hline Total & 90 & $4,778.3$ & $1,910.4$ & $1,756.3$ & 15.4 & 0.8 \\
\hline
\end{tabular}

Source: FAO (1993).

TABLE 2

Global Trends In LAND AREA And Use, 1980-1995

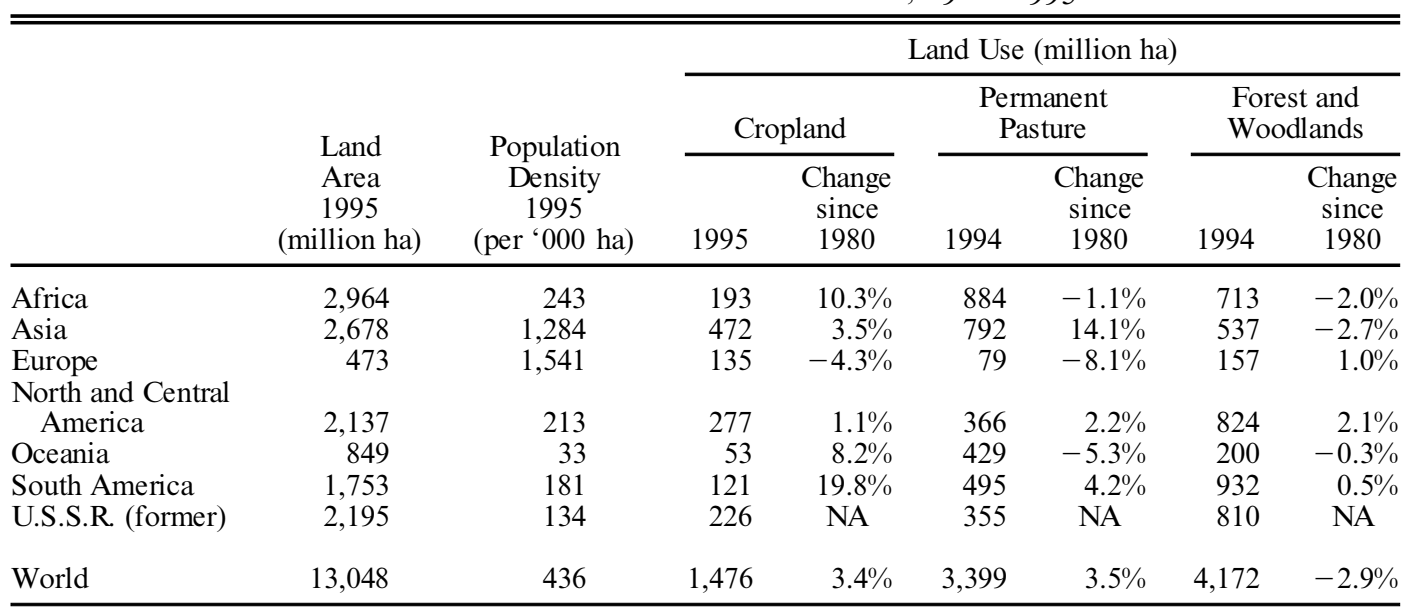

Source: FAO (1997).

NA $=$ Not available. 
TABLE 3

Global Trends in Agricultural Productivity and InPut Use, 1979-1995

\begin{tabular}{|c|c|c|c|c|c|c|c|c|}
\hline & \multirow{2}{*}{$\begin{array}{c}\text { Cropland } \\
\text { (million ha) } \\
1995\end{array}$} & \multirow{2}{*}{$\begin{array}{c}\text { Cropland } \\
\text { per capita } \\
1995\end{array}$} & \multicolumn{2}{|c|}{$\begin{array}{l}\text { Cereal Yields } \\
(\mathrm{kg} / \mathrm{ha})\end{array}$} & \multicolumn{2}{|c|}{$\begin{array}{l}\text { Irrigated Land } \\
\text { as a \% of } \\
\text { Cropland }\end{array}$} & \multicolumn{2}{|c|}{$\begin{array}{l}\text { Fertilizer Use } \\
\text { (kg) per ha of } \\
\text { Cropland }\end{array}$} \\
\hline & & & 1980 & 1995 & $1979-81$ & 1995 & $1979-81$ & 1995 \\
\hline Africa & 193 & 0.27 & 1,124 & 1,128 & 6 & 6 & 18 & 18 \\
\hline Asia & 472 & 0.14 & 2,072 & 3,060 & 29 & 35 & 67 & 144 \\
\hline Europe & 135 & 0.19 & 3,655 & 4,316 & 10 & 12 & 225 & 156 \\
\hline \multicolumn{9}{|l|}{ North and Central } \\
\hline America & 277 & 0.61 & 3,260 & 3,918 & 10 & 11 & 91 & 89 \\
\hline Oceania & 53 & 1.87 & 1,089 & 1,886 & 4 & 5 & 37 & 46 \\
\hline South America & 121 & 0.38 & 1,710 & 2,606 & 7 & 8 & 45 & 54 \\
\hline U.S.S.R. (former) & 226 & 0.77 & NA & 1,301 & 8 & 9 & 80 & 19 \\
\hline World & 1,476 & 0.26 & 2,160 & 2,752 & 15 & 17 & 81 & 89 \\
\hline
\end{tabular}

Source: FAO (1997).

$\mathrm{NA}=$ Not available.

\section{OVERVIEW OF CROSS- COUNTRY ANALYSES: KEY FACTORS AND PROBLEMS}

As noted above, an important area of economic research into tropical deforestation consists of cross-country, regional, and selective country-level statistical analyses of the factors determining declining forest cover. Several surveys have illustrated and synthesized the important findings of this growing literature (Brown and Pearce 1994; Kaimowitz and Angelsen 1998; van Kooten, Sedjo, and Bulte 1999). These surveys suggest that the following key factors have an important influence on tropical deforestation both within and across countries:

income;

population growth/density;

agricultural prices/returns;

agricultural yields;

agricultural exports/export share;

logging prices/returns/production;

roads and road building;

scale factors (size of forest stock, land area, etc.); and

institutional factors (political stability, property rights, rule of law, etc.).

However, the literature has also pointed out a number of problems confronting crosscountry analysis of deforestation. First, the United Nations Food and Agricultural Orga- nization (FAO), which has been the international agency responsible for compiling forest area data across all countries, based its 1990 global forest resource assessment on population growth projections in order to overcome an inadequate forest data base for some countries and regions. This means that the FAO country forest cover data are inappropriate for cross-country analyses of deforestation that use demographic factors as explanatory variables. As the list above indicates, the latter are considered important variables explaining global deforestation. This in turn means that cross-country analyses that employ the FAO forest cover data since 1990 are unreliable. ${ }^{3}$

In addition, time series data on some of the factors listed above, especially agricultural and logging returns or roads and road investments, are simply unavailable across many tropical countries. Thus these factors are more readily incorporated into deforestation analyses for single countries than across tropical regions or countries. The data sets for many other variables across countries also tend to be incomplete. For example, it may be possible to obtain export unit values

\footnotetext{
${ }^{3}$ The inappropriateness of using the FAO 1990 assessment based country forest cover estimates in crosscountry deforestation analyses has been pointed out by Barbier and Burgess (1997), Cropper and Griffiths (1994) and Deacon (1999).
} 
for logs for a tropical country, but it may be more difficult to get an average domestic stumpage value for that country. Agricultural prices for specific crops may be available, but a reliable food or cereal price index for a country may not exist. Data on key institutional factors generally exist for a relatively small number of developing countries, and these factors tend to be averages over long periods of time.

Finally, some approaches to cross-country analyses have a tendency to be ad hoc. The danger with analyzing deforestation across countries is that too much emphasis can be placed on trying to discover factors that explain trends in changes in forest cover rather than on examining a plausible hypothesis as to why certain economic factors might be correlated with deforestation. However, not all studies suffer from an ad hoc approach to cross-country analysis. In recent years, there have been a number of studies that have attempted to develop a specific model or approach to explaining deforestation, and then have tested the resulting hypothesis. The following section identifies four such approaches in the literature.

\section{FOUR APPROACHES TO CROSS- COUNTRY ANALYSES}

\section{Environmental Kuznets Curve (EKC) Analyses}

The environmental Kuznets curve hypothesizes that an environmental "bad" first increases, but eventually falls, as the per capita income of a country rises. Although the EKC model has generally been applied to pollution problems, there have been a number of recent studies that have also examined whether this hypothesis also holds for global deforestation (e.g., Antle and Heidebrink 1995; Cropper and Griffiths 1994; Koop and Tole 1999; Panayotou 1995; Shafik 1994). The basic EKC model for deforestation is usually

$$
\begin{aligned}
F_{i t}-F_{i t-1} & =F\left(Y_{i t}, Y_{i t}^{2 ;} ; z_{i t}\right) \\
& =\alpha_{1} Y_{i t}-\alpha_{2} Y_{i t}^{2}+z_{i t} \beta+\varepsilon_{i t},
\end{aligned}
$$

where $F_{i t}-F_{i t-1}$ is the change in the forest stock over the previous period (which is neg- ative if deforestation is occurring), $Y_{i t}$ is per capita income and $\mathbf{z}_{\mathbf{i t}}$ represents a vector of other explanatory variables, such as population density or growth and other macroeconomic variables. ${ }^{4}$

The application of such an EKC model to explain deforestation trends across countries has produced mixed results. When the model is tested for both temperate and tropical countries, it is inconclusive (Antle and Heidbrink 1995; Panayotou 1995; Shafik 1994). When applied to just tropical countries, the inverted-U relationship tends not to hold for all countries but may apply to specific regions. For example, Cropper and Griffiths (1994) find some evidence that the EKC model is relevant to Latin America and Africa. However, for each of these regions the turning point - the per capita income level at which the deforestation rate is zero and is about to decline-is generally two to four times higher than the average per capita income for that region.

In addition, the EKC relationship is likely to vary considerably from country to country. Through employing a random coefficients panel analysis, Koop and Tole (1999) were unable to reject the hypothesis that countryspecific coefficients are likely to vary compared to cross-country averages (i.e., in Equation [1] $\alpha_{1}=\alpha_{1}, \alpha_{2}=\alpha_{2 i}$ for all $i=1$, $\ldots, N$ countries in the sample). This in turn implies that each tropical forest country or region is likely to have its own unique $\mathrm{EKC}$ relationship, which explains why obtaining a single relationship across all countries may be difficult or implausible.

\section{Competing Land Use Models}

Some empirical analyses have taken as their starting point the hypothesis that forest

\footnotetext{
${ }^{4}$ Strictly speaking, deforestation is defined as (minus) the percentage change in forested area, or $\left(F_{i t-1}-\right.$ $\left.F_{i t}\right) / F_{i t-1}$. However, deforestation is clearly related to the change in forest stock variable, $F_{t}-F_{t-1}$, in equation [1]. In fact, various cross-country analyses have tended to use either specification as the dependent variable to represent forest loss. To simplify notation, $F_{t}-$ $F_{t-1}$ is used in equation [1] and subsequent equations as a short-hand expression for deforestation.
} 
loss in tropical countries is the result of competing land use, in particular between maintaining the natural forest and agriculture (e.g., Barbier and Burgess 1997; Ehui and Hertel 1989). As indicated in Table 2, the evidence across tropical regions is that substantial conversion of forest and woodlands to agriculture is occurring. From an economic standpoint, such conversion implies that potential timber and environmental benefits from forest land are irreversibly lost. Therefore, competing land use models usually include some measure of the "price" or opportunity cost of agricultural conversion and deforestation in terms of the foregone benefits of timber production and environmental benefits from forest land

$$
F_{i t}-F_{i t-1}=A^{D}\left(v_{i t} ; z_{i t}\right), \partial A^{D} / \partial v_{i t}<0,
$$

where $v_{i t}$ is the opportunity cost or "price" of agricultural conversion, $A^{D}$ is the demand for converting forest land to agriculture, and as before $z_{i t}$ represents exogenous economic factors (e.g., income per capita, population density).

A cross-country analysis of [2] was conducted by Barbier and Burgess (1997) for tropical countries for the five-year change in forested area over 1980-1985. The results indicated that increased population density increases forest clearance, whereas rising income per capita and agricultural yields reduce the demand for forest conversion. The latter effects suggest that as countries develop economically and the productivity of their existing agricultural lands improve there is less pressure for deforestation.

However, there were some problems with the analysis that illustrate the general difficulty of applying a competing land use model across tropical forest countries. First, the authors had to use a "proxy" for $v_{i t}$, as preferred measures of the "opportunity cost' of conversion (e.g., land values, timber rents) are not available across countries. Although several proxies were employed, including export unit values for timber, only roundwood production per capita proved to be significant. This variable turned out to be positively related to the five year change in forest area, which the authors concluded was not surprising, given that over the 19801985 period much agricultural conversion occurred in tropical forests that were first " opened up" by timber operations.

The competing land use model is not necessarily inconsistent with a possible EKC relationship between deforestation and income. To test for the latter hypothesis, Burgess (2000) re-analyzed the original data set used by Barbier and Burgess (1997), but did not find any evidence of a significant EKC relationship for tropical countries as a group over the $1980-1985$ period.

\section{Forest Land Conversion Models}

Many country-level studies of tropical deforestation have focused on the forest land conversion decision of agricultural households (e.g., Barbier 2000; Barbier and Burgess 1996; Chomitz and Gray 1996; Cropper, Griffiths, and Mani 1999; López 1997; Nelson and Hellerstein 1996; Panayotou and Sungsuwan 1994). Such approaches model the derived demand for converted land by rural smallholders, and assume that the households either use available labor to convert their own land or purchase it from a market. This in turn allows the determinants of the equilibrium level of converted land to be specified. In such models, the aggregate equilibrium level of cleared land across all households is usually hypothesized to be a function of output and input prices and other factors affecting aggregate conversion

$$
\begin{aligned}
A_{i t}^{D}= & A^{D}\left(p_{i t}, w_{L_{i t}}, \mathbf{w}_{\mathrm{it}} ; \mathbf{x}_{\mathbf{i t}}, \mathbf{z}_{\mathrm{it}}\right), \frac{\partial A^{D}}{\partial p_{i t}}>0, \\
& \frac{\partial A^{D}}{\partial w_{L_{i t}}}<0, \frac{\partial A^{D}}{\partial x_{i t}}>0 .
\end{aligned}
$$

where $p$ is the price of agricultural output, $w_{L}$ is rural wage (labor is a key component in land clearing), $\mathbf{w}$ is a vector of other inputs, $\mathbf{x}$ are factors influencing the "accessibility" of forest areas (e.g. roads, infrastructure, distance to major towns and cities), and as before $\mathbf{z}_{\text {it }}$ represents other economic explanatory variables. 
Studies for representative countries in Asia, Africa, and Latin America have tended to confirm the hypothesis suggested in eq. [3] that agricultural conversion is positively related to agricultural output prices and decreases with rural wage rates (Barbier 2000; Barbier and Burgess 1996; López 1997; Panayotou and Sungsuwan 1994). Cropper, Griffiths, and Mani (1999) also provide evidence from Thailand that the accessibility of forest areas, in this case measure by distance from Bangkok, increases forest land conversion to agriculture. Chomitz and Gray (1996) and Nelson and Hellerstein (1996) include location-specific input and output prices to investigate the impact of roads on the agricultural land conversion decision.

Although the land conversion model appears to work well for specific tropical forest countries, it is difficult to obtain time series data on agricultural input and output prices (especially rural wage rates) for many tropical countries. Cross-country data on important ' $x$ " variables, such as rural road expansion and road building investments, are also hard to find. This means that applying the model to a cross-country panel data set is very problematic.

To date, cross-country analyses of agricultural land conversion have tended to leave out prices and ' $x$ ' factors. For example, Southgate (1994) used annual population growth, agricultural export growth, crop yield growth, and a land constraint dummy to explain annual agricultural land growth across Latin America over 1982-1987. He found that population and agricultural export growth were positively related to land expansion, whereas yield growth and the land constraint were negatively related. Although the results clearly suggest that structural agricultural, economic and geographic factors are significant in explaining land conversion, data constraints meant that the analysis was unable to test the key relationships of the complete forest land conversion model [3].

\section{Institutional Models}

In recent years, a variety of empirical analyses at both the country and cross-country level have explored the impact on tropical deforestation of institutional factors, such as land use conflict, security of ownership or property rights, political stability, and the "rule of law" (e.g., Alston, Libecap, and Mueller 1999, 2000; Deacon 1994, 1999; Godoy et al. 1998). The main hypothesis tested is that such institutional factors are important factors explaining deforestation

$$
F_{i}-F_{i t-1}=F\left(\mathbf{q}_{\mathrm{it}} ; \mathbf{z}_{\mathrm{it}}\right)
$$

where $\mathbf{q}_{\mathrm{it}}$ is a vector of institutional factors and $\mathbf{z}_{\mathbf{i t}}$ is a vector of other economic explanatory variables.

Deacon (1999) has applied such an approach to explain the 1980-1985 change in forest cover as a fraction of land area across all countries, omitting those countries with forests less than $5 \%$ of land area or with more than $50 \%$ of their forests classified as "'open.' The main institutional variable, ownership security, proved to be significant and positive in all models, suggesting that greater security reduces forest loss. ${ }^{5}$ Excluding agricultural yield variables from the models increased the ownership security coefficient by $25-30 \%$, which indicates that the latter effect operates partly through agricultural yields.

Although such models have demonstrated the importance of institutional factors in determining deforestation, an important question is how much weight should be given to such factors compared to explanatory variables identified by other approaches to crosscountry analyses of forest loss? Nevertheless, by excluding institutional indices, other models applied to cross-country analyses of deforestation may have omitted a potentially important explanatory variable.

However, cross-country data sets on institutional factors exist for only a small sub-set of tropical developing countries. In addition, those indices on political stability, corruption, ownership security, and other institu-

${ }^{5}$ The measure of ownership risk in the study was an index derived by Bohn and Deacon (1997). The index was formed from an estimated investment function that relates investment rates in a cross-country panel to macroeconomic variables and political attributes, including measures of government instability and regime type. 
tional factors that are available for tropical countries tend not to vary much over time, or are constructed as averages over long time periods. Thus the inclusion of institutional indices means the use of a time-invariant variable in a panel analysis explaining forest loss in only a representative sample of tropical countries.

\section{TOWARDS A SYNTHESIS MODEL}

Although each of the above four approaches encounter specific difficulties when applied to cross-country analyses of tropical land use conversion, each model also has produced its own unique insight into the possible factors explaining this land use change. An interesting issue is whether it is possible to construct a synthesis model based on the above approaches. The following model discusses briefly one possible synthesis model and its application to the cross-country analysis of tropical land use change. However, in constructing such a synthesis model, the following points need to be kept in mind:

First, given the problems with recent (i.e., post-1985) FAO forest stock data highlighted above, the synthesis model should concentrate on explaining agricultural land expansion, $A_{i t}-A_{i t-1}$, rather than deforestation across tropical countries. This would mean that the model would be able to explain tropical forest loss at least, under the assumption that

$F_{i t}-F_{i t-1}=-\left(A_{i t}-A_{i t-1}\right)$.

That is, as discussed in the introduction, in most developing countries the major cause of forest loss is presumed to be conversion to agriculture, although the relationship between deforestation and agricultural land expansion may not be as exact as implied by [5] (see Table 2).

Second, any synthesis model should be able to test for more than one key factor explaining land use change identified by the above four approaches, provided that the factors chosen are not mutually exclusive. For example, it should be possible to construct a model that can test for the EKC hypothesis as well as examine the possible influence of institutional factors. On the other hand, given the difficulty in obtaining cross-country time series data on key variables, such as rural wages, roads, other input prices, it is difficult to include variables representing agricultural returns or "accessibility" of forest lands in the model. Thus the problem of applying the forest land conversion model across countries, let alone combining this model with an analysis of a possible EKC influence or institutional factors, still remains.

However, as some studies have demonstrated, structural agricultural, economic and geographic factors that vary from country to country are significant in explaining the different land conversion trends across countries (e.g., Barbier and Burgess 1997; Deacon 1999 and Southgate 1994). These factors may be particularly significant explanatory variables in a cross-country analysis, if variables representing agricultural returns or "accessibility" of forest lands cannot be included due to data limitations. Thus, the synthesis model should include certain "structural" variables $\left(\boldsymbol{s}_{\mathrm{it}}\right)$, such as agricultural yield, cropland share of land area, agricultural export share, and arable land per capita, to capture country-by-country differences in agricultural sectors and land use patterns, as well as other exogenous explanatory variables, $\mathbf{z}_{\text {it. }}$.

Thus a possible synthesis model might look like:

$A_{i t}-A_{i t-1}=A\left(Y_{i t}, Y_{i t}^{2}, \mathbf{s}_{\mathbf{i t}}, \mathbf{z}_{\mathbf{i t}} ; \mathbf{q}_{\mathbf{i}}\right)$.

Finally, as institutional factors $\left(\mathbf{q}_{\mathbf{i}}\right)$ tend to be invariant with time, two versions of the model can be tested, one without and one including $\mathbf{q}_{\mathbf{i}}$.

Model [6] was applied to a panel analysis of tropical agricultural land expansion over 1961-1994, with the dependent variable being the percentage annual change in agricultural land area. ${ }^{6}$ The EKC variables $\left(Y_{i t}, Y_{i t}^{2}\right)$ are represented by gross domestic product (GDP) per capita in constant purchasing

\footnotetext{
${ }^{6}$ Following Barbier and Burgess (1997), topical countries were defined as those countries with the majority of their land mass lying between the tropics.
} 
power parity (1987 \$) and by GDP per capita squared, respectively. The structural variables $\left(\mathbf{s}_{\mathbf{i t}}\right)$ are cereal yield, cropland share of total land area, agricultural export share of total merchandise exports, and arable land per capita. The additional explanatory variables $\left(\mathbf{z}_{\mathbf{i t}}\right)$ are population and GDP growth. The source of data used for these variables was the World Bank's World Development Indicators, which has the most extensive data set for key land, agricultural and economic variables for developing countries over the period of analysis.

Table 4 indicates the results without institutional factors, $\mathbf{q}_{\mathbf{i}}$. Both one-way and two- tested for the sample of all tropical countries, as well as for the regional sub-samples for Africa, Latin America, and Asia. Table 4 displays the results for the preferred models and the relevant statistics. In the table, the parameter estimates are reported as elasticities, in order to facilitate comparison of the effects of the different variables, which are in different units.

Across all tropical countries, the structural variables appear to be the more important explanatory factors determining agricultural expansion. Growth in agricultural land area increases with cropland share of total land area and agricultural export share but declines with cereal yield. GDP per capita

TABLE 4

PANel AnAlysis of TROPICAL Agricultural LAND Expansion, 1961-1994

\begin{tabular}{|c|c|c|c|c|}
\hline \multicolumn{5}{|c|}{$\begin{array}{l}\text { Dependent Variable: Agricultural Land Expansion ( } \% \text { annual change })^{\mathrm{a}} \\
\text { Elasticity Estimates: }\end{array}$} \\
\hline $\begin{array}{l}\text { Explanatory } \\
\text { Variables }\end{array}$ & $\begin{array}{c}\text { All } \\
\text { Countries } \\
(N=656)\end{array}$ & $\begin{array}{c}\text { Africa } \\
(N=168)\end{array}$ & $\begin{array}{c}\text { Latin } \\
\text { America } \\
(N=319)\end{array}$ & $\begin{array}{c}\text { Asia } \\
(N=169)\end{array}$ \\
\hline GDP per capita $^{c}$ & 0.270 & -0.980 & -0.388 & 3.068 \\
\hline$(\mathrm{PPP}$, constant 1987 \$) & $(0.199)$ & $(-1.315)$ & $(-0.109)$ & $(2.667)^{* * *}$ \\
\hline \multirow[t]{2}{*}{ GDP per capita squared } & -0.708 & 0.271 & 0.050 & -1.391 \\
\hline & $(-2.035)^{* *}$ & (1.228) & $(0.036)$ & $(-3.370)^{* * *}$ \\
\hline GDP growth & 0.012 & 0.023 & 0.009 & -0.132 \\
\hline (\% annual change) & $(0.177)$ & $(0.456)$ & $(0.127)$ & $(-0.502)$ \\
\hline Population growth & -0.603 & 0.259 & -0.734 & -0.538 \\
\hline (\% annual change) & $(-1.027)$ & $(0.278)$ & $(-1.234)$ & $(-0.445)$ \\
\hline Cereal yield & -2.248 & -0.250 & -2.632 & -1.678 \\
\hline (kg per hectare) & $(-2.846)^{* * *}$ & $(-0.479)$ & $(-2.028)^{* *}$ & $(-1.644)^{*}$ \\
\hline Cropland share of land & 7.112 & 0.923 & 5.565 & -0.452 \\
\hline$(\%$ of land area) & $(3.550) * * *$ & $(4.249) * * *$ & $(2.485) * * *$ & $(-0.694)$ \\
\hline Agricultural export share & 4.351 & 0.078 & 0.462 & 0.395 \\
\hline ( $\%$ of merchandise exports) & $(2.079)^{* *}$ & $(0.496)$ & $(2.098) * *$ & $(0.967)$ \\
\hline Arable land per capita & 0.355 & -0.695 & -0.263 & 0.406 \\
\hline (Hectares per person) & $(0.163)$ & $(-1.659)^{*}$ & $(-0.163)$ & $(0.665)$ \\
\hline Kuznets Curve & No & No & No & Yes \\
\hline (Turning point estimate) & $(\$ 858)$ & $(\$ 3,706)$ & $(\$ 17,359)$ & $(\$ 6,182)$ \\
\hline$F$-test for pooled model & $3.077^{* * *}$ & 1.398 & $3.323^{* * *}$ & $2.245^{* * *}$ \\
\hline Breusch-Pagan (LM) test & $51.69^{* * *}$ & $5.90 * *$ & $11.23^{* * *}$ & 0.29 \\
\hline Hausman test & $31.97 * * *$ & 2.07 & $15.52 * *$ & 10.88 \\
\hline Adjusted $R^{2}$ & 0.212 & 0.183 & .215 & 0.176 \\
\hline Preferred model & One way & One way & One way & One way \\
\hline & fixed effects & $\begin{array}{l}\text { random } \\
\text { effects }\end{array}$ & fixed effects & $\begin{array}{l}\text { random } \\
\text { effects }\end{array}$ \\
\hline
\end{tabular}

${ }^{a}$ Mean for all countries is $0.64 \%$, for Africa $0.26 \%$, for Latin America $0.75 \%$, and for Asia $0.80 \%$

${ }^{\mathrm{b}} t$-ratios are indicated in parentheses.

${ }^{\mathrm{c}}$ Mean for all countries is $\$ 2,863$, for Africa $\$ 1,230$, for Latin America $\$ 3,654$, and for Asia $\$ 3,029$. PPP is purchase power parity.

$* * *$ Significant at $1 \%$ level; ** significant at $5 \%$ level; * significant at $10 \%$ level. 
squared also has a negative impact on agricultural expansion, although this effect is smaller than for the other significant variables. These results are pretty much replicated for the Latin America sub-sample, with the exception that neither per capita income variable is significant. In Africa, agricultural expansion is explained by cropland share of total land area only, although it is possibly negatively affected by the amount of arable land per capita. The regression for Asia is the only estimation that cannot reject the EKC hypothesis. However, the level of per capita income at which agricultural expansion peaks in Asia is estimated to be $\$ 6,182$, which is approximately double the sample mean. Increases in cereal yields may also possibly slow agricultural land expansion in Asia.

Table 5 repeats the same regressions, but with the inclusion of three institutional variables: a corruption index, a property rights index, and a political stability index. These indices were obtained from the Levine-

\section{TABLE 5}

Panel Analysis of Tropical Agricultural Land Expansion, 1961-1994, INCLUDING INSTITUTIONAL FACTORS

\begin{tabular}{|c|c|c|c|c|}
\hline \multicolumn{5}{|c|}{$\begin{array}{l}\text { Dependent Variable: Agricultural Land Expansion ( } \% \text { annual change })^{\mathrm{a}} \\
\text { Elasticity estimates: }\end{array}$} \\
\hline $\begin{array}{l}\text { Explanatory } \\
\text { Variables }\end{array}$ & $\begin{array}{c}\text { All } \\
\text { Countries } \\
(N=383)\end{array}$ & $\begin{array}{l}\text { Africa } \\
(N=48)\end{array}$ & $\begin{array}{c}\text { Latin } \\
\text { America } \\
(N=233)\end{array}$ & $\begin{array}{c}\text { Asia } \\
(N=102)\end{array}$ \\
\hline GDP per capita $^{c}$ & 4.125 & -25.214 & 7.943 & 0.749 \\
\hline (PPP, constant 1987 \$) & $(3.443)^{* * *}$ & $(-1.388)$ & $(2.595) * * *$ & $(0.200)$ \\
\hline GDP per capita squared & $\begin{array}{l}-1.519 \\
(-2.461)^{* * *}\end{array}$ & $\begin{array}{l}13.984 \\
(1.651)^{*}\end{array}$ & $\begin{array}{l}-3.499 \\
(-2.328)^{* *}\end{array}$ & $\begin{array}{c}-0.699 \\
(-0.528)\end{array}$ \\
\hline GDP growth & -0.066 & -0.088 & -0.066 & 0.010 \\
\hline (\% annual change) & $(-0.778)$ & $(-0.463)$ & $(-0.862)$ & $(0.032)$ \\
\hline Population growth & 1.152 & 2.945 & 1.421 & 4.635 \\
\hline ( $\%$ annual change $)$ & $(2.153)^{* *}$ & $(0.803)$ & $(2.271) * *$ & $(2.510)^{* * *}$ \\
\hline Cereal yield & -0.309 & -0.270 & -0.623 & -2.267 \\
\hline (kg per hectare) & $(-0.577)$ & $(-0.180)$ & $(-0.929)$ & $(-0.783)$ \\
\hline Cropland share of land & 0.433 & 5.364 & 0.789 & 3.541 \\
\hline ( $\%$ of land area) & $(2.064)^{* *}$ & $(0.648)$ & $(2.343)^{* *}$ & (1.474) \\
\hline Agricultural export share & 0.654 & -1.168 & 0.383 & -0.282 \\
\hline (\% of merchandise exports) & $(5.658)^{* * *}$ & $(-1.217)$ & $(2.948)^{* * *}$ & $(-0.421)$ \\
\hline Arable land per capita & -0.043 & -0.970 & 0.358 & -2.842 \\
\hline (hectares per person) & $(-0.174)$ & $(-0.334)$ & $(0.83)$ & $(-1.087)$ \\
\hline Corruption index & 0.840 & 2.779 & 0.249 & 4.447 \\
\hline$($ high $=0$, low $=10)$ & $(1.703) *$ & $(0.105)$ & $(0.345)$ & $(2.251)^{* *}$ \\
\hline Property rights index & -0.395 & -5.266 & -0.363 & 9.440 \\
\hline$($ high $=5$, low $=1)$ & $(-0.590)$ & $(-0.214)$ & $(-0.425)$ & $(1.046)$ \\
\hline Political stability index & 0.613 & -5.266 & 0.494 & -1.429 \\
\hline$($ high $=0$, low $=1)$ & $(1.896)^{* * *}$ & $(0.150)$ & $(2.220)^{* *}$ & $(-0.948)$ \\
\hline Kuznets Curve & Yes & No & Yes & No \\
\hline (Turning point estimate) & $(\$ 5,445)$ & $(\$ 1,211)$ & $(\$ 4,946)$ & $(\$ 1,815)$ \\
\hline Durbin-Watson statistic ${ }^{d}$ & 2.009 & 2.372 & 2.045 & 1.998 \\
\hline Adjusted $R^{2}$ & 0.191 & 0.073 & 0.128 & 0.450 \\
\hline Preferred model & OLS with & OLS with & OLS & OLS with \\
\hline & $A C^{d}$ & $A C^{d}$ & & $A C^{d}$ \\
\hline
\end{tabular}

\footnotetext{
${ }^{a}$ Mean for all countries is $0.61 \%$, for Africa $0.14 \%$, for Latin America $0.66 \%$, and for Asia $0.72 \%$.

${ }^{\mathrm{b}} t$-ratios are indicated in parentheses.

${ }^{c}$ Mean for all countries is $\$ 2,986$, for Africa $\$ 1,211$, for Latin America $\$ 3,675$, and for Asia $\$ 2,246$. PPP is purchase power parity.

d After autocorrelation correction (AC) by Cochrane-Orcutt procedure, if required.

*** Significant at $1 \%$ level; ** significant at $5 \%$ level; * significant at $10 \%$ level.
} 
Loayza-Beck data set used in Beck, Levine, and Loayza (1999) and Levine, Loayza, and Beck (1999), which are available from the Economic Growth Research Group of the World Bank. The corruption and property rights indices are directly from the LevineLoayza-Beck data set and are averaged over 1982-1995. The political stability index was created as a composite index of the average number of revolutions and coups (averaged over 1960-1990), average number of assassinations per million population (averaged over 1960-1990), and an index of ethnic fractionalization (averaged over 19821995). As these indices were not available for all tropical countries in the original sample, the inclusion of these institutional factors reduced the sample sizes of the regressions considerably. In addition, the three indices are time invariant, and with their inclusion in addition to the original explanatory variables of the model, fixed effects regressions cannot be run. ${ }^{7}$

Table 5 indicates that the inclusion of institutional factors has a considerable influence on the analysis. ${ }^{8}$ For all tropical countries, the EKC hypothesis can no longer be rejected, although the estimated EKC turning point is nearly double the mean per capita income for the sample. Population growth, the ratio of cropland to total land area, the share of agricultural exports, and political instability all appear to have a significant and positive impact on agricultural expansion across all tropical countries. The regression for Latin American countries yields similar results, which is not surprising as this region dominates the sample of all countries. However, the estimated EKC turning point for Latin America is only one third larger than the average per capita income of $\$ 3,675$ for the sub-sample. This suggests, that if agricultural land growth does start to slow down as GDP per capita increases, we are likely to observe this phenomenon occurring in tropical Latin America first. For Asia, population growth and lower corruption appear to have a significant and positive influence on agricultural expansion. The latter effect may seem counter-intuitive, although López (1998) has argued that reduced corruption and improved bureaucratic efficiency may actually facilitate the implementation of land and credit policies that stimulate a "race for property rights" to convert forest and other common resource land to agriculture. Finally, given the small number of observations for the African sub-sample, the separate regression for the African region has poor explanatory power and should be ignored.

The above results for the synthesis model provide interesting additional results to existing cross-country analyses of tropical land use and deforestation. First, the pattern of agricultural development, as represented by such structural variables as cropland share of total land area, agricultural export share of total exports, and to some extent, cereal yields, appears consistently to influence tropical agricultural land expansion. Population growth could be an additional factor, especially in Asia. Corruption and political stability may also be important institutional influences, but their significance may vary from region to region. The existence of an EKC effect for agricultural expansion appears to be highly sensitive to the model specification, and the impact of changes in GDP per capita on agricultural expansion is likely to differ considerably across tropical regions.

\section{THE CONTRIBUTION OF THIS SPECIAL ISSUE}

By focusing on specific case studies from tropical regions, the articles comprising this special issue explore in more depth the economic determinants of tropical forest land conversion. In doing this, several new contributions are made.

\footnotetext{
${ }^{7}$ Including the three time-invariant institutional indices in a fixed effects regression leads to collinear regressors (Baltagi 1995). As the institutional indices are in themselves 'weighted' country-specific dummy variables, including the indices in an OLS regression will essentially imitate a fixed effects model. Of course, the estimated coefficients on the institutional variables may also be including the influence of other slow-changing factors that vary across countries.

${ }^{8}$ The failure of the property rights index to be significant in any of the regressions reported in Table 5 may reflect the fact that this variable indicates the degree of protection of private property rights across all sectors of the economy rather than the security of land tenure in the agricultural sector.
} 
Studies on the economics of temperate and tropical forest land are beginning to take into account the location of forests (relative to roads) and spatial features (e.g., size, topography, soil conditions) as factors influencing land use decisions (Parks, Barbier, and Burgess 1998). As noted above, many forest land conversion models incorporate the "accessibility" of forest land as an explicit determinant of the equilibrium level of land converted to agriculture. Previous studies of tropical deforestation have also included location-specific input and output prices to explain the influence of road-building on forest conversion. Several studies in this special issue further illustrate the importance of incorporating spatial and locational variability in the analysis of tropical deforestation and land use.

For example, Cropper, Puri, and Griffiths use a bivariate probit model to explain land clearing and the siting of protected areas in the 17 provinces of Northern Thailand in 1986. The results suggest that steeper slopes, higher elevations, and locations further from market centers increase the chance that forest land is designated a protected area or a wildlife sanctuary. However, whereas there is weak evidence to suggest that the creation of wildlife sanctuaries may have deterred deforestation in Northern Thailand, protected areas overall (i.e., wildlife sanctuaries plus national parks) did not reduce the probability of land clearing. Finally, the authors also used their model to demonstrate where further road building in Northern Thailand may have the greatest impact on the probability that forests are cleared, and to identify the impact of additional road building on protected areas through simulation (see Figures 5 and 6 in Cropper, Puri, and Griffiths).

Nelson, Harris, and Stone combine spatial and institutional analysis to investigate the hypothesis that providing land users with secure property rights will result in more sustainable land use and less deforestation. A multinomial logit model incorporating both socioeconomic and geophysical variables is used to evaluate land use patterns in three locations in Darién Prvovince, Panama-a national park where no human activity is supposed to occur plus two long-standing re- serves for indigenous peoples, Cemaco and Sambú Reserves. The authors employ their model to simulate the effects on land use of removing legal protection of the park and the two reserves. The results suggest that legal protection of the national park has made little difference to land use within the park, as its difficult terrain and remoteness limit any profitable activity in this area. In contrast, as construction of the Pan American highway in the early 1980s increased accessibility to the Cemaco Reserve, legal property rights in the reserve clearly serve to limit encroachment from outsiders. The need for effective property rights is less important for Sambú Reserve, as this area is far from the nearest primary road.

Köhlin and Parks develop a household spatial model to examine how the options of collecting fuelwood from the natural forest, from village woodlots, or from both locations impact on deforestation in Orissa, India. Using survey data from 742 village households, the discrete decision of whether to collect from the natural forest is first estimated using a probit model, and then the decision to spend time collecting is analyzed using a sample selection procedure. The main finding is that village woodlots can reduce the pressure on natural forests for fuelwood collection, but woodlots closer to the forest appear to be less used than those located further away. However, plantations very far from the natural forest also do not reduce the use of the forest for fuel biomass. The result is an inverted-U relationship between the distance of the woodlot from the natural forest and the probability that a household will reduce its fuelwood collection from the forest (see Figure 1 in Köhlin and Parks). This implies that the location of a village woodlot will have a considerable impact on whether it is effective in reducing fuelwood collection by households from the natural forest.

Another innovative approach that can be used to examine the effects of economy-wide and sectoral changes on tropical land use and deforestation is computable general equilibrium (CGE) modeling. Two papers in this special issue, Cattaneo and Bashassha, Kraybill, and Southgate, employ this approach.

Cattaneo develops a CGE model to assess 
the impacts on deforestation in the Brazilian Amazon of changes in the real exchange rate, agricultural taxes and price supports, road construction, land tenure, and technological change in agriculture. The differences in the short- and long-run deforestation rates predicted by the model illustrate how interregional flows of labor and capital are critical to the process of agricultural conversion in the Amazonian frontier forest. If recent trends in road building continue to lower transport costs in the region, deforestation is likely to accelerate. On the other hand, deforestation could be significantly reduced if the Brazilian government adopts a balanced contraction policy in response to any real exchange rate devaluation. However, because significant agricultural reforms are already in place in Brazil, the scope for abolishing subsidies or imposing a revenue-neutral tax in agriculture to reduce deforestation is limited. Within the Amazon, improving land tenure security would reduce deforestation significantly, although implementing this policy in the frontier region would be extremely difficult. Finally, the impacts of technological change are mixed: in the livestock sector, deforestation would be increased, although the income of producers would also rise; in the annual crops sector, deforestation would also increase, but producer income would not; and in the perennial crops sector, deforestation would be reduced while producer income would rise.

Bashaasha, Kraybill, and Southgate construct a CGE model to explore the market and land use impacts of agricultural intensification and fuelwood taxation in Uganda. Their results suggest that technologically neutral improvements in agricultural productivity across all sectors of the rural economy increases cash crop exports, raises domestic food consumption, and reduces forest loss. In contrast, targeting a single agricultural sector with high demand elasticity, such as export crops, will cause an expansion of cropped area at the expense of natural forest. Fuelwood taxation proves to be an ineffective instrument for reducing deforestation, and would be an extremely unpopular policy if implemented in Uganda. The authors conclude that improvements in agricultural pro- ductivity and overall development across Uganda are more effective approaches to mitigating deforestation than either targeting improvements to specific agricultural sectors or implementing a fuelwood tax.

The next two papers in this issue are concerned with exploring upland land use decisions and forest clearing in the Philippines. In both cases, the authors focus on the economic linkages between upland activities and markets as determinants of the land clearing decisions of upland households.

Coxhead, Rola, and Kim examine the hypothesis that national markets and policies play a significant role in determining the land expansion and allocation decisions of upland farmers in Lantapan Watershed, the Philippines. Previous studies in this region have confirmed that upland farmers do respond to relative prices and their variability in making their land use decisions. By employing vector auto-regression techniques, Coxhead, Rola, and Kim are able to demonstrate that there is also a strong degree of interconnectedness between corn, potato, and cabbage prices in the local Lantapan market and prices in regional and national markets. The results indicate that in the short run the markets for these crops are integrated, and that upland farmers are essentially price takers with respect to regional and national markets. This suggests that economy-wide and trade policies will affect land use decisions in the Philippine uplands, and in particular, trade liberalization is likely to reduce farm-gate prices of corn and vegetables, the two most environmentally damaging crops grown in Lantapan and similar watersheds in the Philippines.

Shively investigates the impact of rural employment opportunities in lowland areas of the Philippines on the labor and land allocation decisions of upland farmers. In particular, the focus is on how changes in technology in lowland agriculture, including irrigation development, affect land-clearing decisions in the uplands. To do this, the author develops a model linking lowland and upland household activity, which was then applied to two upland and two lowland communities in Palawan. The results indicate that irrigation development in the lowlands does 
lead to increased hiring of upland workers, and in response to such off-farm employment opportunities upland farmers will reduce their rates of forest clearing. Lowland agricultural intensification, particularly in areas adjacent to uplands, can therefore reduce pressure on forests in marginal upland farming areas. Policies that encourage the use of rural labor in these lowland agricultural areas, either explicitly or through improvements in cropping intensity, could reduce upland deforestation significantly.

As noted above, institutional factors have been increasingly viewed as important determinants of deforestation. Of particular concern is the lack of property rights in frontier forested areas, which leads to a de facto open access situation and excessive clearing. As Angelsen suggests, under these conditions, possible land use and deforestation outcomes on the frontier can be modeled as a twoplayer game in which a given forest area can end up being allocated in three different ways: it can be converted to agricultural land by the local community; it can be converted to plantations, logging or other large scale projects by the state; or it can remain as natural forest. When the scarcity of and competition for forest land are very strong, and either the local community or the government acts as leader in a Stackelberg game to "squeeze out" the other agent, then the result is increased deforestation. Evidence from Sumatra, Indonesia, and Brazil cited by the author indicates situations in which local communities "race" to establish their claims by clearing forested land. Further evidence from Indonesia demonstrates how state-supported logging, transmigration, and plantation projects have in the past both supplanted local communities and led to excessive forest conversion. Finally, Angelsen (1999) also confirms that state "planned" deforestation can also promote further deforestation by local communities, particularly if state activities lead to increased infrastructure and roadbuilding in forested areas and thus lower the costs of local agricultural expansion.

One of the key state-sponsored investments in tropical forests is logging activities, as governments are able to earn significant revenues from harvesting royalties. How- ever, it has been argued that most royalty systems in tropical countries may actually increase forest degradation and conversion through incentives for poor logging practices. In the final paper of this special issue, Amacher, Brazee, and Witvliet investigate this important linkage by examining how selective harvesting of high-valued species in timber concessions in Sabah, Malaysia, are affected by the royalty structure. The authors find that, as harvesting of the high quality species is price elastic, forest degradation can be significantly reduced per additional dollar of government revenue earned if royalty reform includes increasing the differentiation in tax rates for high- versus low-valued species. However, to reduce degradation and increase revenues, the government would clearly prefer a differentiated lump sum royalty, whereas to increase its share of rents, a concessionaire would prefer a differentiated ad valorem royalty. Nevertheless, royalty reform could promote more sustainable forestry in Malaysia and similar countries, especially if the gains in revenues through differentiated royalties were re-invested in reforestation programs or intensive management of secondary forests.

\section{CONCLUSION}

The economics of tropical deforestation and land use has consisted of two distinct "waves" of analysis. This introduction to the special issue has conducted a brief overview of the cross-country analyses of the causes of tropical deforestation that typify the "first wave," and has attempted a synthesis analysis of the factors influencing agricultural land expansion across countries. The results suggest that the pattern of agricultural development across these countries appears to affect the growth in agricultural land area, which tends to be the predominant cause of forest loss in tropical regions. Population growth may also matter, especially in Asia. Institutional factors are also important influences, although their inclusion in crosscountry analyses is still constrained by the lack of data for some countries as well as the limited appropriateness of those institutional indices that are available (e.g., the property 
rights index used in the synthesis analysis of this introduction). Finally, the impact of changes in per capita GDP on agricultural expansion varies considerably from region to region, and does not always exhibit an EKCtype relationship.

As the articles in this special issue demonstrate, "second wave" country case studies are able to investigate in much more detail other key factors that influence the economics of tropical deforestation and land use. For example, the papers by Cropper, Puri and Griffiths, Nelson, Harris, and Stone, and Köhlin and Parks illustrate through spatial analysis the importance of location, the "accessibility" of forests and other geographical factors in explaining forest land use patterns, whether it be land clearing and the siting of protected areas in Thailand, the impact of property rights on land use in Panama, or the impact of the location of woodlots on fuelwood collection from natural forests by rural households in India. Similarly, Cattaneo and Bashaasha, Kraybill, and Southgate show how CGE modeling in Brazil and Uganda, respectively, can be an effective tool for investigating a variety of economy-wide and sectoral policy impacts on agricultural expansion and deforestation.

Coxhead, Rola, and Kim and Shively both focus on how external market forces may affect the land-clearing decisions of upland farmers in the Philippines. Coxhead, Rola, and Kim demonstate that farmers are highly responsive to changes in regional and national crop prices, whereas Shively indicates how technological change and increased employment opportunities in lowland agricultural areas influence the labor and land decisions of upland farmers.

The role of the state in influencing both local patterns of deforestation in remote frontier forested areas and forest degradation by major state-supported activities, such as the timber industry, also needs more careful analysis. Such analysis is the focus of the final two articles in this special issue, by Angelsen on game-theoretic, land use decisions on the open-access frontier and by Amacher, Brazee, and Witvliet on harvesting royalties in the Malaysia. Both papers demonstrate that the state is not "passive" with regard to frontier forest loss and degradation, but can have considerable impact on deforestation through the way in which it "sponsors" plantations, logging, and other largescale commercial activities on the frontier, or through the structure of taxes that it imposes on such enterprises, such as the royalties paid by timber concessionaires.

In sum, the articles in this special issue illustrate how innovative economic models can be used effectively to investigate a range of important influences on tropical land use changes in a variety of representative developing countries. It is hoped that this issue will inspire others to pursue novel and insightful studies into the economics of tropical deforestation and land use.

\section{References}

Alston, Lee J., Gary D. Libecap, and Bernardo Mueller. 1999. Titles, Conflicts, and Land Use: The Development of Property Rights and Land Reform in the Brazilian Amazon Frontier. Ann Arbor: University of Michigan Press.

. 2000. "Land Reform Policies, the Sources of Violent Conflict, and Implications for Deforestation in the Brazilian Amazon." Journal of Environmental Economics and Management 39 (2): 162-88.

Angelsen, Arild. 1999. "Agricultural Expansion and Deforestation: Modelling: The Impact of Population, Market Forces, and Property Rights.' Journal of Development Economics 58 (Apr.): 185-218.

Antle, John M., and George Heidebrink. 1995. "Environment and Development: Theory and International Evidence.' Economic Development and Cultural Change 43 (3): 603-25.

Baltagi, Badi H. 1995. Econometric Analysis of Panel Data. Chichester, U.K.: John Wiley.

Barbier, Edward B. 1997. "The Economic Determinants of Land Degradation in Developing Countries.' Philosophical Transactions of the Royal Society, Series B 352 (1356): 891-99.

. 2000. "Institutional Constraints and Deforestation.', Paper presented at the 2000 Royal Economic Society/Scottish Economic Society Conference, St Andrews, Scotland, July 10-13, 2000.

Barbier, Edward B., and Joanne C. Burgess. 1996. "Economic Analysis of Deforestation in Mexico.' Environment and Development Economics 1 (2): 203-40. 
1997. "The Economics of Tropical Forest Land Use Options.' Land Economics 73 (May): 174-95.

Beck, Thorsten, Ross Levine, and Norman Loayza. 2000. "Finance and the Sources of Economic Growth.' Journal of Financial Economics 58 (1-2): 261-300.

Bohn, Henning, and Robert T. Deacon. 1997. ' Ownership Risk, Investment, and the Use of Natural Resources.' Department of Economics, University of California, Santa Barbara. Working Paper.

Brown, Katerina, and David W. Pearce, eds. 1994. The Causes of Tropical Deforestation: The Economic and Statistical Analysis of Factors Giving Rise to the Loss of the Tropical Forests. London: University College London Press.

Burgess, Joanne C. 2000. "The Economics of Tropical Forest Land Use." Ph.D. diss., Economics Department, University College London.

Chomitz, Kenneth M., and David P. Gray. 1996. "Roads, Land Markets, and Deforestation: A Spatial Model of Land Use in Belize.' The World Bank Economic Review 10 (3): 487512.

Cropper, Maureen, and Charles Griffiths. 1994. "The Interaction of Population Growth and Environmental Quality.' American Economic Review, AEA Papers and Proceedings, 84 (2): 250-54.

Cropper, Maureen, Charles Griffiths, and Muthukumara Mani. 1999. "Roads, Population Pressures, and Deforestation in Thailand, 1976-1989.' ' Land Economics 75 (Feb.): 5873.

Deacon, Robert T. 1994. "Deforestation and the Rule of Law in a Cross-Section of Countries." Land Economics 70 (Nov.): 414-30.

—. 1999. "Deforestation and Ownership: Evidence from Historical Accounts and Contemporary Data.' Land Economics 75 (Aug.): 341-59.

Ehui, Simeon K., and Thomas W. Hertel. 1989. "Deforestation and Agricultural Productivity in the Côte d'Ivoire.' American Journal of Agricultural Economics 71 (Aug.): 703-11.

Food and Agricultural Organization (FAO). 1993. Forest Resources Assessment 1990: Tropical Countries. Rome: FAO.

1997. State of the World's Forests 1997. Rome: FAO.

Godoy, Ricardo, Marc Jacobson, Joel De Castro, Vianca Aliago, Julio Romero, and Allison Davis. 1998. "The Role of Tenure Security and Private Time Preference in Neotropical
Deforestation.' Land Economics 74 (May): $162-70$.

Kaimowitz, David, and Arild Angelsen. 1998. Economic Models of Tropical Deforestation: A Review. Bogor, Indonesia: Center for International Forestry Research.

Koop, Gary, and Lise Toole. 1999. "'Is There an Environmental Kuznets Curve for Deforestation?', Journal of Development Economics 58 (July): 231-44.

Levine, Ross, Norman Loayza, and Thorsten Beck. 2000. "Financial Intermediation and Growth: Causality and Causes.' Journal of Monetary Economics 46 (1): 31-77.

López, Ramón. 1997. “Environmental Externalities in Traditional Agriculture and the Impact of Trade Liberalization: The Case of Ghana." Journal of Development Economics 53 (July): $17-39$

1998. "Where Development Can or Cannot Go: The Role of Poverty-Environment Linkages.' In Annual Bank Conference on Development Economics 1997, ed. B. Pleskovic and J. E. Stiglitz, 285-306. Washington D.C.: The World Bank.

Myers, Norman. 1979. The Sinking Ark: A New Look at the Problem of Disappearing Species. Oxford: Pergamon Press.

Nelson, Gerald C., and Daniel Hellerstein. 1997. "Do Roads Cause Deforestation? Using Satellite Images in Econometric Analysis of Land Use.' American Journal of Agricultural Economics 79 (2): 80-88.

Panayotou, Theodore. 1995. "Environmental Degradation at Different Stages of Economic Development.' In Beyond Rio: The Environmental Crisis and Sustainable Livelihoods in the Third World, ed. I. Ahmed and J. A. Doeleman. London: MacMillan Press.

Panayotou, Theodore, and Somthawin Sungsuwan. 1994. "An Econometric Analysis of the Causes of Tropical Deforestation: The Case of Northeast Thailand.' 'In The Causes of Tropical Deforestation: The Economic and Statistical Analysis of Factors Giving Rise to the Loss of the Tropical Forests, ed. K. Brown and D. W. Pearce, 192-210. London: University College London Press.

Parks, Peter J., Edward B. Barbier, and Joanne C. Burgess. 1998. "The Economics of Forest Land Use in Temperate and Tropical Areas." Environmental and Resource Economics 11 (3-4): 473-87.

Shafik, Nemat. 1994. "Economic Development and Environmental Quality: An Econometric Analysis.' Oxford Economic Papers 46 (Oct.): 757-73. 
Southgate, Douglas. 1994. "Tropical Deforestation and Agricultural Development in Latin America.' In The Causes of Tropical Deforestation: The Economic and Statistical Analysis of Factors Giving Rise to the Loss of the Tropical Forests, ed. K. Brown and D. W. Pearce, 134-45. London: University College London Press. van Kooten, G. Cornelius, Roger A. Sedjo, and Erwin H. Bulte. 1999. "Tropical Deforestation: Issues and Policies.' In The International Yearbook of Environmental and Resource Economics 1999/2000, ed. H. Folmer and T. Tietenberg, 199-248. London: Edward Elgar. 